\title{
DIAGNOSTICS OF COMPOSITE AIRCRAFT STRUCTURES USING NON-DESTRUCTIVE TESTS WITH THERMOGRAPHIC, ULTRASOUND AND ACOUSTIC METHODS
}

\author{
Krzysztof Dragan \\ Lukasz Kornas \\ Adam Latoszek \\ Michał Salacinski
}

Air Force Institute of Technology, Warsaw, Poland

\section{INTRODUCTION}

Control and constant supervision over the technical condition of composite constructions of the aircraft are the activities necessary for the safety of exploitation. Even small damage of the composite aircraft structures, caused mainly by heavy loads and changeable atmospheric conditions, will weaken the structure and may lead to serious accidents. Having this in mind, periodical controls using non-destructive tests are conducted. The most popular methods widely used in aviation are those based on ultrasound and acoustic phenomena occurring in examined structures [2]. Ultrasound method consists in emitting ultrasound waves from a transmitter into the material. The material has defects (borders of connections, delaminations) which are the reflector from which the wave reflects and comes back to the transmitter head. Examination of this phenomenon is based on observing the amplitude volume and direction changes of ultrasound waves and on the time measurements of the wave passing through the examined material [4]. Other techniques used for detecting defects in composite structures are ultrasound resonant techniques based on the measurement of resonant vibrations of a given material. Continuous waves introduced into the material are gained or damped. Amplitude and phase of vibrations on the material surface depend on the flexural modulus and thickness of the material placed under the head [3]. Acoustic impedance is another physical phenomenon used (method-MIA). The method is based on the resistance (dampening) measurement of acoustic waves with a specific volume of the examined material.

The above-mentioned non-destructive tests are not the only techniques of examining the composite structures. Due to improvement of composite structures, engineers are forced to implement the latest examination methods. One of these methods is pulsed thermography. This method consists in even activation of the structure by thermal pulse and monitoring changes in temperature distribution of the examined surface, while it is cooling down, by means of the TV camera. Defected areas lose heat much slower and therefore they are characterized by temperature higher than the areas free of material defects [1]. 
a.
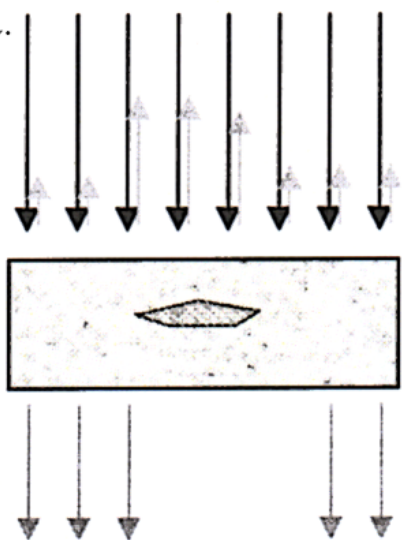

b.

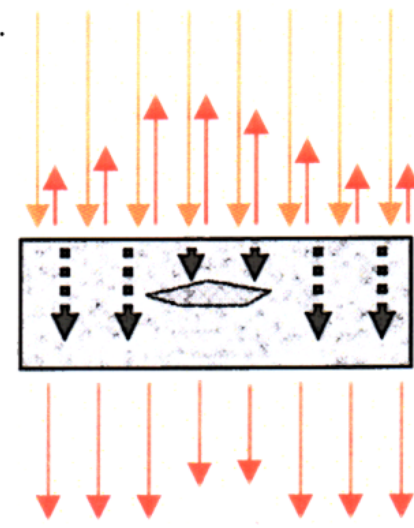

Drawing 1. Presentation of physical phenomena similarities in the examined material: a) dispersion of ultrasound waves; b) dispersion of thermal wave

This work presents examination results of individual techniques demonstrated on composite samples of the laminar and sandwich structure as regards damage characterized by ungluing of glued joints and delamination. Defects detection levels were verified depending on the sizes of the defects. Presenting individual methods aims at highlighting their respective advantages and disadvantages as well as the optimal ways of applying them in normal conditions.

\section{EXPERIMENTAL PART}

\subsection{Research materials and equipment}

Typical materials used in aviation were used in the examinations conducted. Composite samples of the laminar and sandwich structure were used for conducting the examinations.

The automated MAUS system, equipped with exchangeable heads, and the presentation of results in $\mathrm{C}$ mode-Scan were used for controlling composite structures with acoustic and ultrasound methods. EchoThermSystem equipped with xenon lamps and a professional TV camera was used as the research equipment based on pulsed thermography.

- Composite plate reinforced with carbon fibres.

\begin{tabular}{|c|l|l|}
\hline Pulsed thermography method & Ultrasound method & Sample \\
\hline Examination time $2 \mathrm{~s}$ & 1 & \\
\hline & Examination time 40s & \\
\hline
\end{tabular}


- Plate manufactured on the basis of glass fibres of the laminar structure.

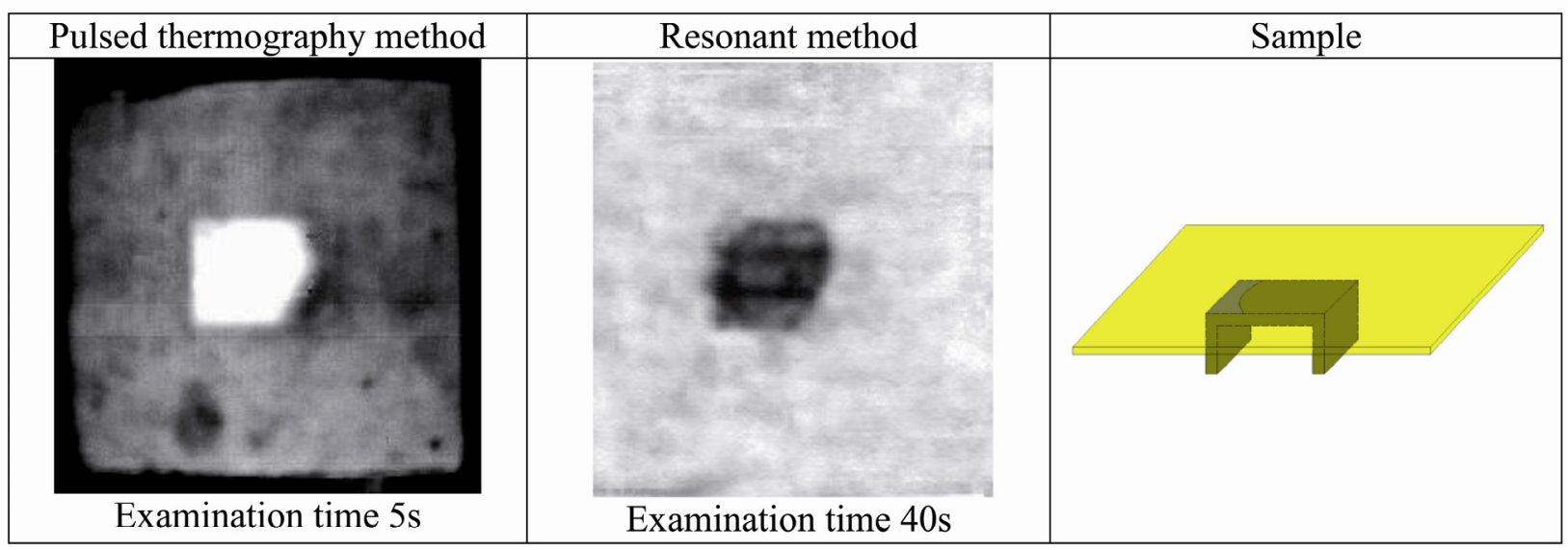

- Composite plate with foam core reinforced with carbon fibres.

\begin{tabular}{|c|c|c|}
\hline Pulsed thermography method & Acoustic impedance method; MIA & Sample \\
\hline & & \\
\hline Examination time $60 \mathrm{~s}$ & Examination time $50 \mathrm{~s}$ & \\
\hline
\end{tabular}

\section{SUMMARY}

The aim of the conducted tests was to estimate the flaw detection rate of composite structures and glued joints. Not all methods applied allow detection of material defects in the examined structure. The problems concern the inspection of the sandwich structure e.g. foam core, which has muffling characteristics eliminating the application of the ultrasound method, whereas the method of acoustic impedance delivers information about the internal structure of the examined material. The technique of pulsed thermography allows acquiring information about the imperfections of the structure in a wide range of composite materials [5] from a wide range of surfaces in a relatively short time (a couple of seconds) compared to acoustic and ultrasound methods, during which the time of examination is longer and dependent on the size of the scanned surface. Thermographic images (thermographs) reflect the physical condition of examined samples and internal flaws in the material can be detected, however their geometry and location influence the accuracy of the method. For the interpretation of the examination results, the special software can be used in order to increase the accuracy of the surface analysis by means of differentiation of the first and second degree of temperature curves at a given point. 


\section{REFERENCES}

[1] Wiera Oliferuk Termografia aktywna $w$ badaniach materiatów, Instytut Podstawowych Problemów Techniki, PAN Warszawa.

[2] Barbara Surowska Materiały funkcjonalne $i$ złożone $w$ transporcie lotniczym, Politechnika Lubelska.

[3] Góra G., Mackiewicz S., Ultradźwiękowe badania konstrukcji kompozytowych w przemyśle lotniczym, Jedenaste Seminarium Nieniszczące Badania Materiałów, Zakopane 2005.

[4] Anna Lewińska - Romicka Badania nieniszczqce; Podstawy defektoskopii Wydawnictwo Naukowo - Techniczne Warszawa.

[5] Steven M. Shepard, James R. Lhota, Yulin Hou, Tasdiq Ahmed and David Wang Thermographic characterization of composite materials and structures. Thermal Wave Imaging, Inc. 